\title{
Influence of Organizational Commitment and Self Efficacy on Employee Performance Through Job Satisfaction as Intervening Variables
}

\author{
Amalia Rizka Putri ${ }^{1}$, Tantri Yanuar Rahmat $S_{y a h}{ }^{2}$ \\ Esa Unggul University, Jakarta, Indonesia ${ }^{1,2}$
}

\begin{abstract}
The purpose of research is to determine the effect of Organizational Commitment (X1) and Self Efficacy (X2) on Employee Performance (Y) through Job Satisfaction as intervening variable (Z) on PT Media Indra Buana employees, Central Jakarta. The subsequent purpose of this study are finding correlation between variables and measure the covariance that testing using structural equation modeling method. Respondents of this research are employees of PT. Media Indra Buana, Central Jakarta. The results showed that organizational commitment has no effect on job satisfaction, Organizational Commitment influence to Performance, Self Efficacy have an effect on Job Satisfaction, Self Efficacy have an effect on Employee Performance and Job Satisfaction has no effect to Employee Performance.
\end{abstract}

Keywords: Organizational Commitment, Self Efficacy, Job Satisfaction, Employee's Performance

\section{INTRODUCTION}

Globalization and modernization in the industrial field almost exclude the willingness of employees who want to work, but the employee will still be needed by the company, because without employees a company impossible to walk by itself. Employees are always involved in every management and operational process within a company, the linkage of compensation to employee performance is very significant. Another factor that can affect performance is employee job satisfaction. Job satisfaction is the level of a person's feelings of pleasure as a positive assessment of his work and the environment where his work. Job satisfaction is a variable attitude that describes how a person perceives his work as a whole as well as various aspects of the job. Satisfaction can be viewed as a statement of the positive outcome of an employee's assessment of what the company has done to its employees. Employees with high job satisfaction will experience positive feelings when they think about their duties or take part in task activities, whereas employees with low job satisfaction will experience negative feelings when they think about their duties or take part in their work activities. Organizational commitment is one of the factors that can affect the performance of the employee. An employee in running a job in a company has a very basic problem where one employee with another will not be the same level of commitment. Strong organizational commitment within the individual will cause the individual to work hard to strive to achieve predetermined organizational goals. Highly committed employees will try to do their best for the organization. Furthermore, other factors that can affect the performance of employees is self efficacy, Self efficacy itself is a belief that someone has to kemampuandiri that is on him to do something. In everyday life self efficacy leads us to determine challenging ideals and stay afloat in the face of difficulties. When problems arise, strong sense of self efficacy encourages the individual to remain calm and seek solutions rather than contemplating his disability. Effort and persistence produce achievement. It will cause confidence to grow. Self efficacy such as self-esteem grows with the achievement of performance. Employee performance and job satisfaction are important in the field of human resource management. Employee performance, job satisfaction, organizational commitment and self-efficacy are interrelated variables to help improve employee performance. Organizational commitment and high self efficacy will support one's confidence in achieving its goals and achieve high job satisfaction resulting in performance in accordance with the will of the company. This study examines further from preliminary research conducted in human resource studies Mathieu and Zajac (1990) on Organizational Commitment and job satisfaction are related variables and affect job performance (job performance). Furthermore, the researcher examines self efficacy and job satisfaction conducted by Judge and Bono (2001), lis (2016) that self efficacy is the related variable and affect job satisfaction and employee performance. To enrich a more in-depth literature review of organizational commitment to research performance conducted by Witaliza (2012), Ahmad et al. (2010), Susanty (2013). Furthermore, the researcher did the development of previous research conducted by Susanty and Miradipta (2013 which use organizational commitment variable as independent job satisfaction variable as interpersonal variable and employee performance as independent variable.In this research, the researcher add self efficacy variable as independent variable that will influence job satisfaction and performance employees. 


\title{
International Advanced Research Journal in Science, Engineering and Technology
}

\author{
Vol. 5, Issue 8, August 2018
}

Deepening of research conducted by researchers with emphasis on organizational commitment and self efficacy as a variable that can affect the dependent variable. Self efficacy is also mostly used for research institutions and researchers try to analyze a company. And the method of analysis used in this research is structural equation modeling. There are also other differences, in the previous research testing done at a manufacturer company. While in this study the research will be tested on one of the advertising companies. With this distinction, the researcher aims to make the resulting findings can be used on a larger scale and can be applied to a wider field.

\section{LITERATURE REVIEW}

\section{Organizational Commitment}

Organizational Commitment can be defined as the degree to which an employee identifies himself / herself with the organization and organizational goals, as well as the employee's expectation to stay in the organization (Robbins, 2008). Organizational commitment to L. Mathis and Jackson (2001) "organizational commitment is the degree to which employees believe and accept organizational goals that will remain or will not leave the organization.

\section{Self Efficacy}

Kreitner and Knicki (2008) stated that self efficacy is a person's belief about his chances to succeed in doing specific tasks. According Lahey (2009) self efficacy is defined as the perception that a person is able to do what is necessary to achieve the goal. It means being able to know what to do and be emotionally able to do it. People who have high self efficacy can accept bigger challenges, spend more effort, and may be more successful in achieving goals as a result. People who have low self efficacy get no promotion at work because they do not involve themselves to contribute well to the organization.

\section{Job satisfaction}

Job satisfaction demonstrates the suitability between a person's expectations and the rewards provided by the job, so job satisfaction is also closely related to the theory of justice, psychological agreement and motivation (Robbins and Judge, 2009). Further, Robbins and Judge (2009) define job satisfaction as a general attitude of an individual to his work where in a job someone is required to interact with colleagues and superiors, follow the rules and policies of the organization, meet the standards of performance.

Richard, Robert and Gordon (2012) assert that job satisfaction relates to a person's feelings or attitudes about the job itself, salary, promotional or educational opportunities, supervision, co-workers, workload and so on.

\section{Performance}

Bernardin and Russel (2003) provide the following definition or performance: "performance is defined as the record of outcomes produced on a specified job function or activity during the time period". Performance or performance is a record of the results obtained from certain job functions or activities over a period of time. According to Mathis and Jackson (2006) employee performance is the contribution that employees provide to companies that can be identified from the work of employees. The performance of individual employees is a factor that affects the success of an organization.

\section{RESULT AND DISCUSSION}

\section{Relationship between Organizational Commitment and Job Satisfaction}

Commitment is the emotional attachment and involvement of an organization. This organizational commitment is influence or developed, if involvement in the organization proves to be a rewarding experience that can provide an opportunity to do the job better or generate an opportunity to gain valuable skills, meaning employee commitment to the organization or company affect their job satisfaction.

Markovits et al. (2007), research conducted by Sharma and Bajpai (2010) and Adeloka (2012) stated that organizational commitment is proven to be a catalyst for improving employment and employee satisfaction. Research conducted by Tilaar et al. (2014) states that organizational commitment is influential on job satisfaction. Beman and Strasser (1984) put forward organizational commitment to be antecedent to job satisfaction. Kreitner and Kinicki (2014) also revealed that Organizational commitment is very important. Almost every individual expresses a significant relationship and strong between organizational commitment and job satisfaction.Based on the description, the hypothesis proposed in this study are:

\section{H1: Organizational commitment have an effect positive to job satisfaction}




\title{
International Advanced Research Journal in Science, Engineering and Technology
}

\author{
Vol. 5, Issue 8, August 2018
}

\section{Relationship between Organizational Commitment and Employee Performance}

Organizational commitment shows employees' attitudes in identifying their involvement in the organization. Organizational commitment is built on employees' trust in organizational values, employees' willingness to help realize organizational goals, and loyalty to remain members of the organization. Organizational commitment will create a sense of ownership for employees of the organization. When an employee feels involved and has a loyalty with the organization then he will feel happy in working and feel obliged to advance the company so that its performance can increase.

Fu and Deshpande (2014) examined the effect of organizational commitment on employee performance in the insurance company. The research results stated that organizational commitment had positive and significant impact on employee performance. This was in line with Yeh and Hong (2012) research which stated organizational commitment positively affect employee performance. Khan (2010) that organizational commitment affect the employee performance. Based on the description, the hypothesis proposed in this study are:

H2: Organizational commitment has a positive effect on employee performance.

\section{Relationship between Self Efficacy with Job Satisfaction}

Self-efficacy is one of the personal factors that mediate or mediate in the interaction between behavioral factors and environmental factors. Self-efficacy can be a determinant of successful performance and implementation of the work. Self-efficacy also greatly affect the mindset, emotional reactions in making decisions. Job satisfaction (job satisfaction) is a pleasant emotional attitude and love his work (Hasibuan, 2009). Based on the above understanding, it can be said that the placement of employees have an influence on job satisfaction.

Understanding is supported by research Chasanah (2008) The results of data processing shows that the self-efficacy of job satisfaction and employee performance. Lau (2012), in his study of 224 students at a university in the United States showed that self-efficacy positively related to job satisfaction. Other studies also suggest that self-efficacy has a positive effect on job satisfaction (Samuel, 2013). It can be said that the higher one's self-efficacy the higher one's job satisfaction and the lower one's self-efficacy, the lower the level of job satisfaction. Self-efficacy has an effect on job satisfaction. This proves that self-efficacy owned by employees provides support to their job satisfaction. Because they assume that basically every person must have self-efficacy, but the self-efficacy is formed because of support from the company. Based on the description, the hypothesis proposed in this study are:

H3: Self-efficacy has a positive effect on job satisfaction.

\section{Relationship between Self-efficacy with Employee Performance}

Self-efficacy is one of the personal factors that mediate or mediate in the interaction between behavioral factors and environmental factors. Self-efficacy can be a determinant of successful performance and job implementation. Selfefficacy also greatly affects the piker pattern, the emotional reactions in making decisions. According Sinambela et al. (2012) suggests that the performance of employees is defined as the ability of employees in doing certain skills. Thus it can be said that self efficacy can improve individual performance. Meta analysis performed by Judge and Bono (2001) found a positive relationship between self efficacy and individual performance. Research conducted by Erez and Judge (2001) also states there is a positive and significant relationship between self-efficacy and individual performance. Based on the description, the hypothesis proposed in this research are:

H4: Self-efficacy has a positive effect on employee performance.

\section{Relationship between Job Satisfaction and Employee Performance}

Job satisfaction is the most important factor to get optimal results when a person feels satisfaction in working of course he will do everything possible with all the capabilities it has. Job satisfaction of an employee will affect the results obtained from his work. High work spirit of course that will encourage these employees in improving performance in work so as to boost employee performance in total.

In previous research as delivered by Amburgey (2005), said that job satisfaction has a positive and significant effect on employee performance. The better employee job satisfaction will improve employee performance. Carmeli and Freund (2004) showed that job satisfaction has a positive and significant effect on employee performance. When employees are satisfied with their work, they see themselves as an integral part of the organization, so they will dedicate themselves to the organization (Kristianto et al., 2012). Luthas (2006) states that employee satisfaction has a positive effect on employee performance.Based on the description, the hypothesis proposed in this study are:

H5: job satisfaction has a positive effect on employee performance 


\section{International Advanced Research Journal in Science, Engineering and Technology}

Vol. 5, Issue 8, August 2018

From the description above, we can describe the research model as follows:

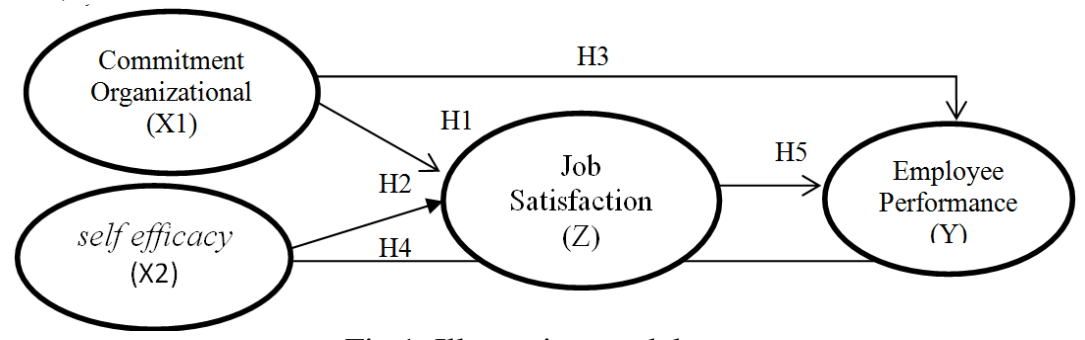

Fig 1. Illustration model

In this study, the population is employees of PT. Media Indra Buana. The sample in this study was obtained as many as $33 \times 5=165$ Respondents. In accordance with the analysis tool that will be used is Structural Equation Model (SEM) then the determination of the minimum number of representative samples). Structural Equation Modeling (SEM) data processing technique with Confirmatory Factor Analysis (CFA) method is used in this research. Observed variables (indicators) illustrate a particular latent variable (latent dimension). As a testing method that combines analysis factors, path analysis and regression. SEM is more a confirmatory rather than an explanatory method, aimed at evaluating proposed dimensionally proposed and derived prior research. With this understanding, SEM can be used as a tool to confirm pre-knowledge that has been previously obtained.

Structural Model Analysis: The results of this analysis are also used for testing the research hypothesis. The statistical test for hypothesis of causal relation of structural model is done with $5 \%$ significance level $(0,05)$, so the critical value of $t$ is +1.96 . The parameters estimated for the causal relation of this model are $\gamma \mathrm{ij}, \zeta \mathrm{i}, \beta \mathrm{ij}, \xi_{\mathrm{ij}}$. The estimation results of all the causal relationships can be seen in the following table:

TABLE 1 Structural Model Equation Table

\begin{tabular}{|c|c|}
\hline No & Regresi \\
\hline 1 & 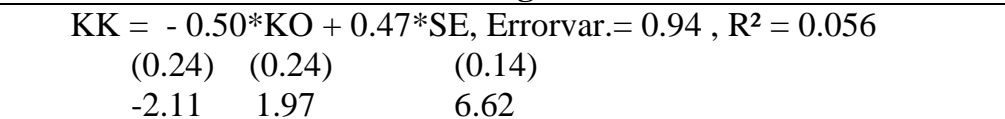 \\
\hline 2 & $\begin{array}{l}\mathrm{KI}=0.034 * \mathrm{KK}+0.49 * \mathrm{KO}+0.42 * \mathrm{SE}, \text { Errorvar. }=0.22, \mathrm{R}^{2}=0.78 \\
0.61 \\
\begin{array}{ccccc}(0.055) & (0.17) & (0.17) & (0.076) \\
2.89 & 2.51 & 2.87\end{array}\end{array}$ \\
\hline
\end{tabular}

From the table can be seen, the value of $\mathrm{R} 2$ for each equation. This $\mathrm{R} 2$ value serves to show how far each independent variable is able to explain its dependent variable. The above results can be analyzed as follows first, job satisfaction affects organizational commitment and self efficacy with $\mathrm{R}^{2}=0,056$. It shows that the $5.6 \%$ variant of job satisfaction can be explained by organizational commitment variable and self efficacy while the remaining $94.4 \%$ can be explained by other variables not found in this study. Second, job Satisfaction, Organizational Commitment and Self Efficacy with $\mathrm{R}^{2}=0.78$. This shows that $78 \%$ of the variants of organizational commitment, self efficacy and job satisfaction can be explained by employee performance while the remaining $22 \%$ can be explained by other variables not found in this study.

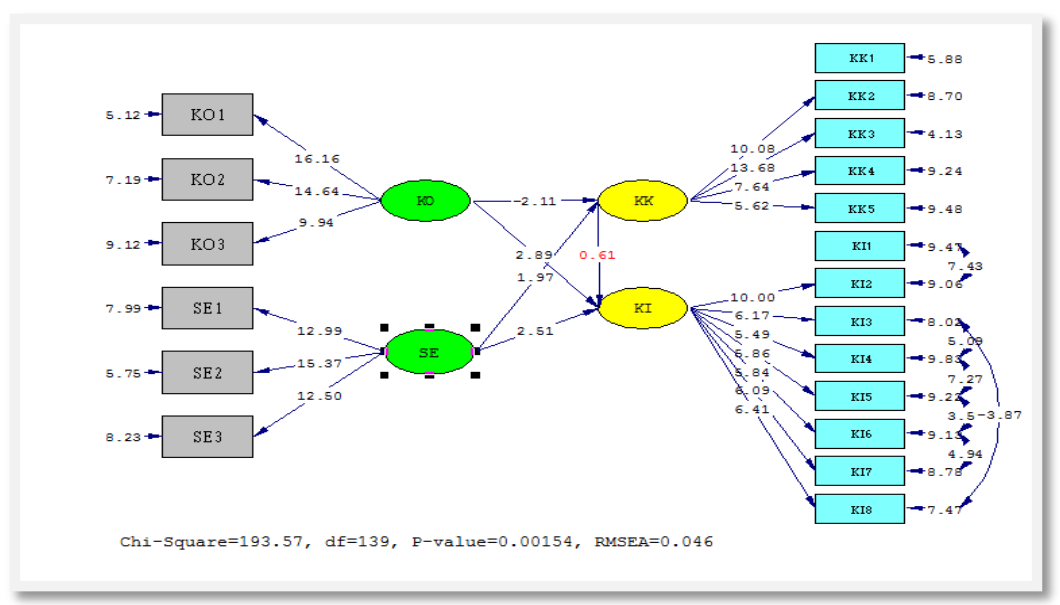

Fig 2, data processed by researchers, 2018 


\section{International Advanced Research Journal in Science, Engineering and Technology}

Vol. 5, Issue 8, August 2018

TABLE 2 Hypothesis Statement Hypothesis Value-t value Description

\begin{tabular}{|c|l|c|c|}
\hline Hypothesis & \multicolumn{1}{|c|}{ Hypothesis statement } & t-value & Description \\
\hline H1 & $\begin{array}{l}\text { Organizational commitment has a positive effect } \\
\text { on job satisfaction }\end{array}$ & $-2,11$ & $\begin{array}{c}\text { Data does not support } \\
\text { the hypothesis }\end{array}$ \\
\hline H2 & $\begin{array}{l}\text { Organizational Commitment has a positive effect } \\
\text { on employee performance }\end{array}$ & 2,89 & $\begin{array}{c}\text { Data support the } \\
\text { hypothesis }\end{array}$ \\
\hline H3 & $\begin{array}{l}\text { Self Efficacy has positive effect on job } \\
\text { satisfaction }\end{array}$ & 1,97 & $\begin{array}{c}\text { Data support the } \\
\text { hypothesis }\end{array}$ \\
\hline H4 & $\begin{array}{l}\text { Self efficacy has a positive effect on employee } \\
\text { performance }\end{array}$ & 2,51 & $\begin{array}{c}\text { Data support the } \\
\text { hypothesis }\end{array}$ \\
\hline H5 & $\begin{array}{l}\text { Job Satisfaction has a positive effect on employee } \\
\text { performance }\end{array}$ & 0,61 & $\begin{array}{c}\text { Data does not support } \\
\text { the hypothesis }\end{array}$ \\
\hline
\end{tabular}

The result of testing the hypothesis found the result for the first organizational commitment does not increase job satisfaction the hypothesis is unacceptable, the results of the study show that organizational commitment has no positive effect on job satisfaction. Second organizational commitment improves performance are hypothesis acceptable result of research indicate that organizational commitment have positive influence to performance.

1. Self Efficacy Increase Job Satisfaction

The hypothesis is acceptable. The results showed that self efficacy has a positive effect on job satisfaction. So it can be concluded that any change in self efficacy will result in changes in job satisfaction.

\section{Self Efficacy Improve Performance}

The hypothesis is acceptable. The results show that self efficacy has a positive effect on employee performance. Experience will be success, other individual experiences, verbal persuasion and physiological state. Based on several statements in the questionnaire in this study, to create self-efficacy influential, then there must be some psychological state in the employees, first, the cognitive process is the ability of employees in analyzing and expressing ideas to achieve the desired goals.

\section{Satisfaction Does Not Increase Performance}

The hypothesis is unacceptable because the value of T-values is smaller. The results showed that job satisfaction has no positive effect on employee performance.

\section{MANAGERIAL IMPLICATIONS}

Based on the test results of organizational commitment and self efficacy on employee performance through job satisfaction. There are some things that can be used as input or reference for the three companies that become the object of research in this study. Some recommendations of leaders strategic actions in developing employees' emotional attachment to the company include: communicating the goals and objectives of the company clearly and consistently, creating rules and practices that can stimulate employee engagement, link organizational goals with the day-to-day work of the employees, open between senior managers, managers and employees, rewarding managers who are able to create and improve employee engagement, be able to listen to what employees want and what they need, provide opportunities and challenges to explore potentials employees, clarity on how employees can contribute, and finally, reward employees for their contributions

\section{CONCLUSION}

This study aims to prove and analyze the influence of organizational commitment to employee job satisfaction, organizational commitment to employee performance, the influence of self efficacy on job satisfaction, the influence of self efficacy on employee performance and the last influence of job satisfaction on employee performance. In measuring organizational commitment the researchers used the dimensions of Meyer, Allen and Smith (1993), selfefficacy using dimensions from Schwarzer and Jerusalem (1993), job satisfaction using Luthans dimension (2005) and employee performance using dimensions from Robins (2006). Based on the results of research and analysis that have been done and discussions described in the previous chapter, it can be concluded as follows:

First, organizational commitment variables do not have a positive effect on job satisfaction. It can be concluded that organizational commitment has no role in employee job satisfaction in PT Media Indra Buana, Central Jakarta.

Second, the organizational commitment variable has a positive effect on employee performance. It can be concluded that organizational commitment has a role in employee performance PT Media Indra Buana, Central Jakarta 


\title{
International Advanced Research Journal in Science, Engineering and Technology
}

\author{
Vol. 5, Issue 8, August 2018
}

Third, that self efficacy has a positive effect on job satisfaction. It can be concluded that individual employees of PT Media Indra Buana, Central Jakarta have a role in increasing job satisfaction. Fourth self success has a positive effect on employee performance. Can be concluded in improving employee performance PT Media Indra Buana, self efficacy / ability of individual have important role. The five hypotheses tested by the researchers found that job satisfaction did not positively affect the performance of PT Media Indra Buana employees. It can be concluded that job satisfaction has no role to improve employee performance.

Limitations of Research: In this study, researchers are aware and feel there are still many shortcomings and limitations in the implementation that affect the results of research. This limitation can be used as a corrective and learning material in conducting future research. Limitations in this study. Respondents used in this study only come from PT. Media Indra Buana counted 165 respondents. In this study using questionnaires to obtain the required data there are some answers given by respondents to the questionnaire statement that is not in accordance with the real circumstances.

More Advice and Research: Based on the conclusions described in the previous chapter, it is hoped that the results of this study can be used to provide optimal benefits for subsequent research objects and this study can also be a comparison material in other studies. However, as this study has the limitations mentioned above, further research is expected to be expanded and expanded to complement the broader object of research so as to enrich and deepen theories and studies of organizational commitment, self efficacy, job descriptions and comprehensive employee performance. in the aspects of business world implementation, especially in enriching the world of human resource development.

\section{REFERENCES}

[1]. Adeloka. 2012 "The Impact of Organizational Commitment on Job Satisfaction (A Study of Employees at Nigerian University)" journal of management. Vol 2, No.2. pp:1-17

[2]. Adebara et, al. 2016 "Work Environment and Organizational Commitment of Staff Academic Libraries' in Logos State, Nigeria" Journal of Applied Information Science and Technology. Pp:39-48

[3]. Allen, N. J. \& Meyer, J. P. 1993. The Measurement and Antecedents of Affective, Continuance, and Normative Commitment to The Organization. Journal of Occupational Psychology, vol: 63, pp. 1-18.

[4]. Allen, Natalie, J and Jond P. Mayer. 2001. The Measurement and Antecedents of Affective, Continuance And Normative Commitment to the organization. Jurnal of occupational Psychological. The British Psychological Society.

[5]. Ahmad et, al. 2010 "Relationship between Job Satisfaction, Job Performance Attitude toward Work and Organizational Commitment" European Journal of Social Science. Vol 18 No. 2. Pp:257-267

[6]. Al-Hussami. 2008. "A Study of Nurses' Job Satisfaction: The Relationship to Organizational Commitment, Perceived Organizational Support, Transaction Leadership, and Level Education" European Journal of Scientific Research. Vol.22, No.2.pp: 286-295

[7]. Amburgey, W. (2005). An analysis of the relationship between job satisfaction, organizational culture, and perceived leadership characteristics. University of Central Florida. Florida: ProQuest Digital Dissertation.

[8]. Bateman dan Stasser, 1984. "A Longitudinal analysis of antecedents of the antecedent of organizational commitment". Academy of Management Journal.pp:95-112

[9]. Bandura. (1997). Self-Efficacy: The Exercise of Control. New York: W.H. Freeman and Company.

[10]. Baron, Robert A., and Gerald Greenberg. 1990. Behavior in Organization: Under - standing and Managing the Human Side of Work, third edition. Boston: Allyn and Bacon.

[11]. Dessler, G. (2003). Human Resources Management (10 ed.). New Jersey: Prentice Hall.

[12]. Djati dan Khusaini. 2003. "Kajian Terhadap Kepuasan Kompensasi, Komitmen Organisasi dan Presenstasi kerja". Jurnal Manajemen dan Kewirausahaan. Vol.5 No 1, Maret 2003.pp:25- 41

[13]. Fu dan Deshpande. 2014. "The Impact of Caring Climate, Job Satisfaction, and Organizational Commitment on Job Performance of Employees in a China's Insurance Company". Journal of Business Ethics, Vol.124, No.2.pp:339-349.

[14]. Gibson ,Ivancevich, Donnely, Organisasi dan Manajemen, Perilaku Stuktur Proses, Erlangga,Jakarta,1997’

[15]. Hair, J. F., Black, W. C., \& Babin, B. J. (2013). Multivariate Data Analysis (7 ed.). New York: Pearson.

[16]. Judge et, al. 2001. "The Job Satisfaction-Job Performance Relationship: A Qualitative and Quantitative Review:. The American Psychological Association. Vol.127. No. 3.pp:376- 407.

[17]. Judge, T.A dan J.E. Bono. 2001. Relationship of Core Self-Evaluations Traits-Self Esteem, Generalized Self-Efficacy, Locus of Control, and Emotional Stability-With Job Satisfaction and Job Performance: A Meta-Analysis. Journal of Applied Psychology. 86(1): 80-92.

[18]. Khan et al, 2010. "The Impact of Organizational Commitment on Employee Job Performance" European Journal of Social Sciences Vol. 15 No. 3.pp: $292-298$

[19]. Kasegar. 2013. "Pengembangan Karir dan Self-Efficacy terhadap Kinerja Karyawan pada PT Matahari Department Store Manado Town Square". Jurnal EMBA. Vol.1 No.4 Desember 2013.pp: 906-916

[20]. Kreitner dan Kinicki. 2014. Organizational Behavior. Jakarta: Penerbit Salemba Empat. Lis dan Yunus. 2016. "Job Satisfaction as an Intervening Variable of Self Efficacy and Employee Performance” International Journal of Cross Cultural Management, Vol.7 No.1.pp: 284298

[21]. Luthans, Fred. (2005). Organizational Behavior. New York: McGraw-hill. Luthans, Fred. (2006). Perilaku Organisasi, edisi 10. Bandung: Refika Aditama

[22]. Markovits et al., 2007. "Organizational Commitment Profiles and Job Satisfaction among Greek Private and Public Sector Employees". International Journal of Cross Cultural Management, Vol7 No.1.pp:77-99

[23]. Munandar, Ashar Sunyoto. 2008. Psikologi Industri dan Organisasi. Universitas Indonesia, Jakarta

[24]. Noor. Juliansyah, 2011, Metodologi Penelitian, Prenada Media Group, Jakarta Richard L. Hughes, Robert C. Ginnett, and Gordon J. Curphy. 2012. Leadership, Enhancing the Lessons of Experience, Alih Bahasa: Putri Izzati. Jakarta:Salemba Humanika. 


\section{International Advanced Research Journal in Science, Engineering and Technology}

\section{Vol. 5, Issue 8, August 2018}

[25]. Rivai, Vethzal. et, al. (2005). Performance Appraisal: Sistem yang tepat untuk Menilai Kinerja Karyawan dan Meningkatkan Daya Saing Perusahan. Jakarta: PT. Raja Grafindo Persada.

[26]. Robbins, Stephen P, (1996). Perilaku Organisasi Jilid II, Alih Bahasa Hadayana Pujaat maka, Jakarta, Prenhalindo.

[27]. Robbert. L. Mathis \& John H. Jackson, (2006). Human Resource Management: Manajemen Sumber Daya Manusia. Terjemahan Dian Angelia. Jakarta: Salemba Empat.

[28]. Sharma dan Bajpai. 2011. "Organizational citizenship behavior in public and private sector and its impact on job satisfaction: a comparative study in Indian perspective". International Journal of Business and Management. Vol 6 No.1.pp: 67-75

[29]. Sinambela, Lijan. (2012). Kinerja Pegawai: Teori, Pengukuran dan Implikasi. Yogyakarta: Graha Ilmu.

[30]. Susanty Dan Miradipta. 2013. "Analysis of The Effect of Attitude Toward Works, Organizational Commitment, and Job Satisfaction, on Employees Job Performance". European Journal of Business and Social Sciences. Vol 1 No. 10. pp: 15-24

[31]. Sugiyono. 2010. Metode Penelitian Kuantitatif, Kualitatif dan R\&D. Bandung: CV Alfabeta.

[32]. Sugiono. 2014. Metode Penelitian Administrasi. Bandung: Alfabeta Bandung.

[33]. Wijayanto, S. H. (2008). Structural Equation Modeling dengan LISREL 8.8 Konsep dan Tutorial. Yogyakarta: Graha Ilmu.

[34]. Yeh, H and D. Hong. 2012. The Mediating Effect of Organizational Commitment on Leadership Type and Job Performance. The Journal of Human Resource and Adult Learning. Vol. 8, Num. 2, Pp. 50-59.

[35]. Yolandari, V. (2011). Pengaruh Budaya Organisasi, Pengembangan Karir, dan Self-Efficacy Terhadap Kinerja Karyawan PT PLN (Persero) APJ Purwokerto. Skripsi Sarjana pada FE Universitas Jenderal Soedirman Purwokerto.

[36]. Zimmerman, B.J., Kitsantas, A. (1996). Self-Regulated Learning of Motoric Skills: the Roles of Goal Setting and Self-Monitoring. Journal of Applied Sport Psychology, Vol. 8, pp. 69-84. 